\title{
Peripheral Injection of SB203580 Inhibits the Inflammatory-Dependent Synthesis of Proinflammatory Cytokines in the Hypothalamus
}

\author{
Andrzej P. Herman, ${ }^{1}$ Agata Krawczyńska, ${ }^{1}$ Joanna Bochenek, ${ }^{1}$ Hanna Antushevich, \\ Anna Herman, ${ }^{2}$ and Dorota Tomaszewska-Zaremba ${ }^{1}$ \\ ${ }^{1}$ Polish Academy of Sciences, The Kielanowski Institute of Animal Physiology and Nutrition, 05-110 Jabłonna, Poland \\ ${ }^{2}$ The Academy of Cosmetics and Health Care, 13 Podwale Street, 00-252 Warsaw, Poland \\ Correspondence should be addressed to Andrzej P. Herman; a.herman@ifzz.pan.pl
}

Received 24 February 2014; Revised 9 May 2014; Accepted 20 May 2014; Published 4 June 2014

Academic Editor: Kanato Yamagata

Copyright ( 2014 Andrzej P. Herman et al. This is an open access article distributed under the Creative Commons Attribution License, which permits unrestricted use, distribution, and reproduction in any medium, provided the original work is properly cited.

\begin{abstract}
The study was designed to determine the effects of peripheral injection of SB203580 on the synthesis of interleukin- (IL-) $1 \beta$, IL-6, and tumor necrosis factor (TNF) $\alpha$ in the hypothalamus of ewes during prolonged inflammation. Inflammation was induced by the administration of lipopolysaccharide (LPS) $(400 \mathrm{ng} / \mathrm{kg})$ over 7 days. SB203580 is a selective ATP-competitive inhibitor of the p38 mitogen-activated protein kinase (MAPK), which is involved in the regulation of proinflammatory cytokines IL-1 $\beta$, IL-6 and TNF $\alpha$ synthesis. Intravenous injection of SB203580 successfully inhibited $(P<0.01)$ synthesis of IL-1 $\beta$ and reduced $(P<0.01)$ the production of IL-6 in the hypothalamus. The p38 MAPK inhibitor decreased $(P<0.01)$ gene expression of TNF $\alpha$ but its effect was not observed at the level of TNF $\alpha$ protein synthesis. SB203580 also reduced $(P<0.01)$ LPS-stimulated IL-1 receptor type 1 gene expression. The conclusion that inhibition of p38 MAPK blocks LPS-induced proinflammatory cytokine synthesis seems to initiate new perspectives in the treatment of chronic inflammatory diseases also within the central nervous system. However, potential proinflammatory effects of SB203580 treatment suggest that all therapies using p38 MAPK inhibitors should be introduced very carefully with analysis of all expected and unexpected consequences of treatment.
\end{abstract}

\section{Introduction}

Hypothalamus is the brain region responsible for integration and processing of signals from endocrine, nervous, and immune systems. It is well known that inflammatory states influence the activity of neurons located in different hypothalamic nuclei and affect centrally regulated processes such as thermogenesis [1], food intake [2], reproduction [3, 4], and circadian rhythms of rest-activity and sleep [5]. Among the most important mediators that transmit the inflammatory signals from the periphery into brain parenchyma are proinflammatory cytokines. It is well established that inflammatory processes raise the concentration of proinflammatory cytokines such as interleukin- (IL-) $1 \beta$, IL-6, and tumor necrosis factor (TNF) $\alpha$ in the peripheral blood $[6,7]$. During the development of inflammatory response, the increased concentration of proinflammatory cytokines is observed both in the cerebrospinal fluid and in brain parenchyma $[6,8,9]$. The origin of these proinflammatory cytokines in central nervous system seems to be differentiated: the peripheral cytokines can cross the blood-brain barrier through fenestrated brain capillaries in the choroid plexus, organum vasculosum of the lamina terminalis, median eminence, subfornical organ, and area postrema [10]. Moreover, it was described that, in response to peripheral bacterial endotoxin, proinflammatory IL- $1 \beta$ could be synthesized by macrophagelike cells in the circumventricular organs and choroid plexus, where the blood-brain barrier is deficient [11]. During inflammation, the cytokines may be also transported into the brain via blood-brain barrier by saturated, self-inhibitable 
transport mechanisms [12]. However, significant sources of central proinflammatory cytokines may generate their own synthesis within the brain tissue including hypothalamus $[9,13]$. This brain synthesis of proinflammatory cytokines could be induced by a fast neural pathway [11]. It was shown that the electrical stimulation of the vagus nerve induces the expression of brain IL-1, and vagotomy abrogates the induction of expression of brain IL-1 in response to intraperitoneal lipopolysaccharide $[14,15]$. The synthesis of proinflammatory cytokines in brain structures may be also stimulated and controlled by the same cytokines originating from the periphery or produced by the circumventricular organs and choroid plexus. This is because proinflammatory cytokines amplify their own synthesis and secretion [16]. However, an important role in the transmission and amplification of inflammatory signals in the brain may cause auto- and paracrine stimulation of proinflammatory cytokines in the brain tissue. This autostimulatory effect of IL-1 on its synthesis was observed in many cytokine-secreting cells including microglia $[17,18]$. It is well established that central proinflammatory cytokines could directly affect the processes regulated at the level of hypothalamus via their corresponding receptors [19]. Acting centrally proinflammatory cytokines, especially IL-1 $\beta$, are considered to be important modulator of endocrine system. At the level of hypothalamus IL- $1 \beta$ was found to stimulate the hypothalamic-pituitaryadrenal stress axis [20]. On the other hand, the injection of exogenous IL- $1 \beta$ into the region of hypothalamus suppressed secretion of gonadoliberine $(\mathrm{GnRH})$ leading to downstream inhibition of the hypothalamic-pituitary-gonadal axis activity $[21,22]$. Therefore, the reduction of proinflammatory cytokines synthesis in the hypothalamic area may profoundly attenuate the central response on the peripheral inflammation.

The study was designed to determine the effect of peripheral injection of SB203580 on the synthesis of IL$1 \beta$, IL- 6 , and $\mathrm{TNF} \alpha$ in the hypothalamus of ewes during prolonged inflammation. SB203580 is pyridinyl imidazole compound that is a selective ATP-competitive inhibitor of the $\mathrm{p} 38$ mitogen-activated protein kinase (MAPK). It has previously been established that SB 203580 acts primarily to block the catalytic activity of p38 MAPK but not its activation by upstream MAPK [23]. However, it is worth mentioning that biochemical analysis of SB203580 activity showed that this inhibitor lost its specificity when it was used at high concentration and could also suppress activity of other kinases such as lymphocyte kinase, glycogen synthase kinase 3, and protein kinase B [24]. The p38 MAPK is an important mediator of stress-induced gene expression. In particular, the p38 kinase is known to play a key role in LPS-induced signal transduction pathways leading to cytokine synthesis [25]. Previous studies indicated that p38 MAPK is involved in the inflammatorydependent upregulation of proinflammatory cytokines synthesis at the translational and posttranslational levels [23, 26]. It was shown that SB203580 strongly inhibited LPSstimulated synthesis of IL- 6 and TNF- $\alpha$ in hepatic stellate cells [27].

\section{Materials and Methods}

2.1. Animals. The studies were performed on adult, 3-yearold Polish mountain sheep in the anestrous season (AprilMay). All animals were in good condition. The body condition of all animals was estimated at three- on a five-point scale. The animals were maintained indoors in individual pens and exposed to natural daylight. The ewes were well adapted to the experimental conditions and always had visual contact with neighbouring ewes, even during the experimental period. This avoided the stress of social isolation. The animals were fed a constant diet of commercial concentrates with hay and water constantly available.

All procedures on animals were performed with the consent of the Local Ethics Committee of the Warsaw Agriculture University.

2.2. Experimental Procedures. Venous catheters were implanted into the jugular vein on the day prior to the experiment. The ewes $(n=24)$ were randomly divided into four experimental groups: group I-control $(n=6)$; group II-SB203580 treated $(n=6)$; group III-LPS-treated $(n=6)$; group IV-LPS- and SB203580 treated $(n=$ 6). In treated animals, the prolonged immune stress was induced by the intravenous (i.v.) administration of LPS from Escherichia coli 055:B5 (Sigma, St. Louis, MO, USA) dissolved in saline $(0.9 \% \mathrm{w} / \mathrm{v} \mathrm{NaCl})$ (Baxter, Deerfield, IL, USA) at a concentration of $10 \mathrm{mg} / \mathrm{L}$ into the jugular vein $(400 \mathrm{ng} / \mathrm{kg})$. For six days, the animals received a single injection of LPS or saline at $8 \mathrm{am}$. On day 7 of the experiment, 30 mins prior to saline/LPS treatment, ewes from groups II and IV received i.v. injection of SB203580 hydrochloride $(500 \mu \mathrm{g} / \mathrm{kg}$ ) (Axon Medchem BV, Groningen, Netherlands). Concurrently, the animals from the control and LPS treated groups received $2 \mathrm{~mL}$ of saline injection. Animals were euthanized three hours after the LPS/saline injection and the brains were rapidly removed from the skulls. The blocks of brains encompassing hypothalamus were sectioned sagittally and dissected from both sides according to stereotaxic atlas of the sheep brain [28]. Landmarks were the mammillary body, median eminence, and optic chiasm. The depth of the cuts was 2.5 to $3 \mathrm{~mm}$. Following collection, all tissue was divided into two and then frozen in liquid nitrogen and stored at $-80^{\circ} \mathrm{C}$.

\subsection{ELISA Assay for $I L-1 \beta, I L-6$, and TNF $\alpha$ Concentration} in the Hypothalamus. The concentrations of IL-1 $\beta$, IL-6, and TNF $\alpha$ in the hypothalamus were determined using a commercial IL-1 $\beta$, IL-6, and TNF $\alpha$ ELISA kit (BlueGene Biotech CO., LTD., China) designed for sheep. The tissues were homogenized in $1 \mathrm{~mL}$ of cold phosphate buffered saline $(0.02 \mathrm{M})$; then homogenates were subjected to two freeze-thaw cycles to further break the cell membranes. Homogenates were then centrifuged for $15 \mathrm{~min}$ at $1500 \times \mathrm{g}$ at $4^{\circ} \mathrm{C}$. The supernatants were aliquoted and stored until assay at $-80^{\circ} \mathrm{C}$. All steps in the assays were performed according to the manufacturer's instructions. The incubation of plates and absorbance measurement at $450 \mathrm{~nm}$ were performed using a VersaMax reader (Molecular Devices LLC., Sunnyvale, 
TABLE 1: All genes analyzed by real-time PCR are listed with their full name and abbreviation.

\begin{tabular}{|c|c|c|c|c|}
\hline $\begin{array}{l}\text { GenBank acc. } \\
\text { number }\end{array}$ & Gene & $\begin{array}{l}\text { Amplicon size } \\
{[\mathrm{bp}]}\end{array}$ & Forward/reverse & Sequence $5^{\prime} \rightarrow 3^{\prime}$ \\
\hline NM_001034034 & $\begin{array}{l}\text { GAPDH } \\
\text { Glyceraldehyde-3- } \\
\text { phosphate } \\
\text { dehydrogenase }\end{array}$ & 134 & $\begin{array}{l}\text { Forward } \\
\text { Reverse }\end{array}$ & $\begin{array}{l}\text { AGAAGGCTGGGGCTCACT } \\
\text { GGCATTGCTGACAATCTTGA }\end{array}$ \\
\hline U39357 & $\begin{array}{l}A C T B \\
\text { Beta actin }\end{array}$ & 168 & $\begin{array}{l}\text { Forward } \\
\text { Reverse }\end{array}$ & $\begin{array}{l}\text { CTTCCTTCCTGGGCATGG } \\
\text { GGGCAGTGATCTCTTTCTGC }\end{array}$ \\
\hline NM_001076910 & $\begin{array}{l}\text { PPIC } \\
\text { Cyclophilin C }\end{array}$ & 131 & $\begin{array}{c}\text { Forward } \\
\text { Reverse }\end{array}$ & $\begin{array}{l}\text { ACGGCCAAGGTCTTCTTTG } \\
\text { TATCCTTTCTCTCCCGTTGC }\end{array}$ \\
\hline ВC108088.1 & $\begin{array}{l}\text { HDC1 } \\
\text { Bos taurus histone } \\
\text { deacetylase } 1\end{array}$ & 115 & $\begin{array}{l}\text { Forward } \\
\text { Reverse }\end{array}$ & $\begin{array}{l}\text { CTGGGGACCTACGGGATATT } \\
\text { GACATGACCGGCTTGAAAAT }\end{array}$ \\
\hline X54796.1 & $\begin{array}{l}\text { IL-1 } \beta \\
\text { Interleukin-1 beta }\end{array}$ & 137 & $\begin{array}{c}\text { Forward } \\
\text { Reverse }\end{array}$ & $\begin{array}{l}\text { CAGCCGTGCAGTCAGTAAAA } \\
\text { GAAGCTCATGCAGAACACCA }\end{array}$ \\
\hline NM_001206735.1 & $\begin{array}{l}\text { IL-1R1 } \\
\text { Interleukin-1 receptor, type } \\
\text { I }\end{array}$ & 124 & $\begin{array}{l}\text { Forward } \\
\text { Reverse }\end{array}$ & $\begin{array}{l}\text { GGGAAGGGTCCACCTGTAAC } \\
\text { ACAATGCTTTCCCCAACGTA }\end{array}$ \\
\hline NM_001009392.1 & $\begin{array}{l}\text { IL-6 } \\
\text { Interleukin-6 }\end{array}$ & 165 & $\begin{array}{c}\text { Forward } \\
\text { Reverse }\end{array}$ & $\begin{array}{l}\text { GTTCAATCAGGCGATTTGCT } \\
\text { CCTGCGATCTTTTCCTTCAG }\end{array}$ \\
\hline NM_001110785 & $\begin{array}{l}\text { IL-6R } \\
\text { Interleukin } 6 \text { receptor }\end{array}$ & 149 & $\begin{array}{c}\text { Forward } \\
\text { Reverse }\end{array}$ & $\begin{array}{l}\text { TCAGCGACTCCGGAAACTAT } \\
\text { CCGAGGACTCCACTCACAAT }\end{array}$ \\
\hline NM_001024860 & $\begin{array}{l}\text { TNF } \alpha \\
\text { Tumor necrosis factor alpha }\end{array}$ & 153 & $\begin{array}{l}\text { Forward } \\
\text { Reverse }\end{array}$ & $\begin{array}{l}\text { CAAATAACAAGCCGGTAGCC } \\
\text { AGATGAGGTAAAGCCCGTCA }\end{array}$ \\
\hline NM_174674 & $\begin{array}{l}\text { TNFR1 } \\
\text { Tumor necrosis factor } \\
\text { receptor superfamily, } \\
\text { member 1A }\end{array}$ & 137 & $\begin{array}{l}\text { Forward } \\
\text { Reverse }\end{array}$ & $\begin{array}{l}\text { AGGTGCCGGGATGAAATGTT } \\
\text { CAGAGGCTGCAGTTCAGACA }\end{array}$ \\
\hline NM_001040490 & $\begin{array}{l}\text { TNFR2 } \\
\text { Tumor necrosis factor } \\
\text { receptor superfamily, } \\
\text { member 1B }\end{array}$ & 122 & $\begin{array}{l}\text { Forward } \\
\text { Reverse }\end{array}$ & $\begin{array}{l}\text { ACСTTCTTCСТССТСССАAA } \\
\text { AGAAGCAGACCCAATGCTGT }\end{array}$ \\
\hline
\end{tabular}

California, USA). The sensitivity for all assays was $1.0 \mathrm{pg} / \mathrm{mL}$. The significance of the differences in the levels of IL-1 $\beta$ between the experimental groups was assessed by the MannWhitney $U$ test. Statistical significance was defined as $P<$ 0.01 .

2.4. Determining the Relative Gene Expression. Total RNA from hypothalamus was isolated using NucleoSpin RNA II Kit (MACHEREY-NAGEL Gmbh \& Co; Düren, Germany) according to a manufacturer's instruction. The purity and concentration of isolated RNA were spectrophotometrically quantified by measuring the optical density at 230,260, and $280 \mathrm{~nm}$ in a NanoDrop 1000 instrument (Thermo Fisher Scientific Inc., Waltham, USA). The RNA integrity was verified by electrophoresis using $1 \%$ agarose gel stained with ethidium bromide. Maxima First Strand cDNA Synthesis Kit for RT-qPCR (Thermo Fisher Scientific Inc., Waltham, USA) was used to prepare cDNA synthesis. As a starting material for this PCR synthesis $2 \mu \mathrm{g}$ of total RNA was used.

Real-time RT-PCR was carried out using HOT FIREPol EvaGreen qPCR Mix Plus (Solis BioDyne, Tartu, Estonia) components and HPLC-grade oligonucleotide primers synthesised by Genomed (Poland). Specific primers for determining the expression of housekeeping genes and the genes of interest were designed using Primer 3 software (Table 1). One tube contained $4 \mu \mathrm{L}$ PCR Master Mix (5x), $14 \mu \mathrm{L}$ RNase-free water, $1 \mu \mathrm{L}$ primers $(0.5 \mu \mathrm{L}$ each, working concentration was $0.25 \mu \mathrm{M})$, and $1 \mu \mathrm{L}$ cDNA template. The tubes were run on the Rotor-Gene 6000 (Qiagen, Duesseldorf, Germany). The following protocol was used: $95^{\circ} \mathrm{C}$ in 15 mins for activating Hot Star DNA polymerase and finally the PCR including 30 cycles at $95^{\circ} \mathrm{C}$ in $10 \mathrm{sec}$ for denaturation, $60^{\circ} \mathrm{C}$ in $20 \mathrm{sec}$ for annealing, and $72^{\circ} \mathrm{C}$ in $10 \mathrm{sec}$ for extension. After the cycles, a final melting curve analysis under continuous fluorescence measurements was performed to confirm the specificity of the amplification.

Relative gene expression was calculated using the comparative quantification option of Rotor Gene 6000 software 1.7. (Qiagen, Duesseldorf, Germany). The second differential maximum method [29] was used to calculate reaction efficiencies. A set percentage of the maximum fluorescence value was used to calculate the beginning of the exponential phase. To compensate for the variation in cDNA concentrations and the PCR efficiency between tubes, an endogenous control gene was assayed in each sample and used for normalization. 
Initially, four housekeeping genes, GAPDH, $\beta$-actin, PPIC, and $H D C 1$, were tested. The BestKeeper was used to determine the most stable housekeeping gene for normalizing genes of interest expression. The BestKeeper is based on the pair-wise correlation analysis of all pairs of candidate genes $[30]$ and calculates variations of all reference genes $\mathrm{SD}( \pm \mathrm{Ct})$. GAPDH was selected as the best endogenous control gene. It had the lowest $\mathrm{SD}( \pm \mathrm{Ct})$ value and correlation coefficient with the remaining analyzed housekeeping genes.

The results are presented as a relative gene expression of the target gene versus housekeeping gene, relative expression value, and mean \pm S.E.M. The average relative quantity of gene expression in control groups was set to 1.0. The significance of differences between the experimental groups was assessed by the Mann-Whitney $U$ test. Statistical significance was defined as $P<0.01$.

\section{Results}

3.1. Influence of SB203580 and Prolonged LPS Treatment on IL$1 \beta, I L-6$, and TNF $\alpha$ Synthesis in the Hypothalamus. Sevenfold administrations of LPS increased $(P<0.01)$ the amount of all analyzed proinflammatory cytokines in the hypothalamus compared with both control groups. SB203580 decreased $(P<0.01)$ LPS-induced elevation of IL-1 $\beta$ and IL-6 concentration. However, in the group with concomitant SB203580 and LPS treatment the level of IL-6 stayed increased $(P<$ 0.01 ) compared with control groups. On the other hand, the injection of SB203580 did not affect the endotoxin-stimulated TNF $\alpha$ expression in the hypothalamus (Figure 1).

3.2. Effect of SB203580 and Prolonged LPS Treatment on IL$1 \beta$, IL-6, TNF $\alpha$, and Their Corresponding Receptors Gene Expression in the Hypothalamus. Seven days of LPS administration simulated $(P<0.01)$ the gene expression of $I L$ $1 \beta$ (Figure 2), IL-6 (Figure 3), and TNF $\alpha$ (Figure 4) in the hypothalamus. On the other hand, prolonged endotoxin treatment stimulated $(P<0.01)$ only the expression of IL-1R1 gene but had no effect on IL-6R, TNFR1, and TNFR2 mRNA level in the hypothalamus. SB203580 reduced $(P<0.01)$ LPSdependent elevation of IL-1 $\beta$, IL-6, and TNF $\alpha$ as well as IL-1R transcription. However, SB203580 did not completely abolish the effect of inflammation on the gene expression of TNF $\alpha$ and IL-1R1 which stayed increased $(P<0.01)$ compared to the control groups.

\section{Discussion}

Our study demonstrated that prolonged inflammation induced through 7 days of LPS treatment elevated local synthesis of IL- $1 \beta$, IL- 6 , and TNF $\alpha$ in the hypothalamus of sheep. The strongest stimulatory effect of inflammation was determined in the case of IL-6, which showed the highest relative increase in the concentration. These results fully support the data obtained in previous studies with single and repeated LPS injections which reported the potentiation of proinflammatory cytokines synthesis in the brain of mice $[6,31]$. They also determined higher elevation of IL-6
mRNA levels compared with IL-1 $\beta$ and TNF $\alpha$ in response to peripheral inflammatory stimuli. This could have a profound effect on hypothalamic activity. It was concluded that central proinflammatory cytokines, especially IL-1, are able to induce changes in the brain neurochemistry. These cytokines induce norepinephrine release in the brain (most markedly in the hypothalamus), increase brain concentrations of tryptophan and the metabolism of serotonin, decrease acetylcholine secretion, and provoke modest changes in brain dopamine [32]. Among others acting at the level of hypothalamus, proinflammatory cytokines have been identified as being responsible for stimulation of thermogenesis [33], the hypothalamic-pituitary-adrenal axis activation $[34,35]$, and the hypothalamic-pituitary-gonadal axis inhibition [21]. These actions of proinflammatory cytokines in the hypothalamus enable the existence of their corresponding receptors in this region of the brain [19]. The expression of their receptor was determined in microglia, astrocytes, and even neurons [36-39]. In our study prolonged inflammation elevated only IL-1 type I (R1) gene expression but did not influence the transcription of cytokines receptor: IL-6R, TNFR1, and TNFR2 in the hypothalamus. The stimulatory effect of endotoxin treatment on IL-1R1 expression in the brain has been previously described in sheep $[8,40]$ and mice $[41,42]$. This could lead to the assumption that in the hypothalamus peripheral inflammation increases the sensitivity of IL-1R1 expressing cell on the action of IL-1 $\beta$. Although, no affect of peripheral inflammatory stimuli on the gene expression of IL-6R was found in the hypothalamus, it should be pointed out that the amount of mRNA for IL-6 corresponding receptor was the highest among transcripts encoding other analyzed cytokines receptors. Therefore, based on our data it is impossible to judge which cytokine is pivotal in the transmission of the inflammatory effects in this region of the hypothalamus.

The p38 MAPK is one of the three groups of mitogenactivated protein kinases which are key enzymes in the signal transduction cascade from the extracellular environment to the nucleus of essentially every eukaryotic cell type [43]. The p38 MAPKs are strongly activated in vivo by environmental stresses and inflammatory cytokines but less by serum and growth factors. Therefore, together with the JNK family, p38 MAPKs are also known as stress-activated protein kinases [44]. The p38 MAPK was first recognized for its role in inflammation in regulating the biosynthesis of proinflammatory cytokines such as IL-1 and TNF $\alpha$ in endotoxinstimulated monocytes [26]. Subsequently it was also found to be involved in regulating the production of IL- 8 in response to IL- $1 \alpha$ and IL- $1 \beta$ [45] and the production of IL- 6 in response to IL- 1 and TNF $\alpha[43,46]$. The results of the in vitro studies indicate that p38 MAPK inhibition by SB203580 strongly reduces the IL- $1 \beta$ induced synthesis of IL- 6 and indicates that a key element of p38-dependent IL- 6 regulation occurs at the level of mRNA stability [43]. The in vitro experiments also demonstrate that SB203580 inhibits at the dose-dependent manner endotoxin-stimulated expression of IL- $1 \beta$ in the monocytic cell lines [25]. It should be noted that the results of the study performed on rat primary cortical glial cell cultures indicate that inhibition of p38 MAPK by SB203580 


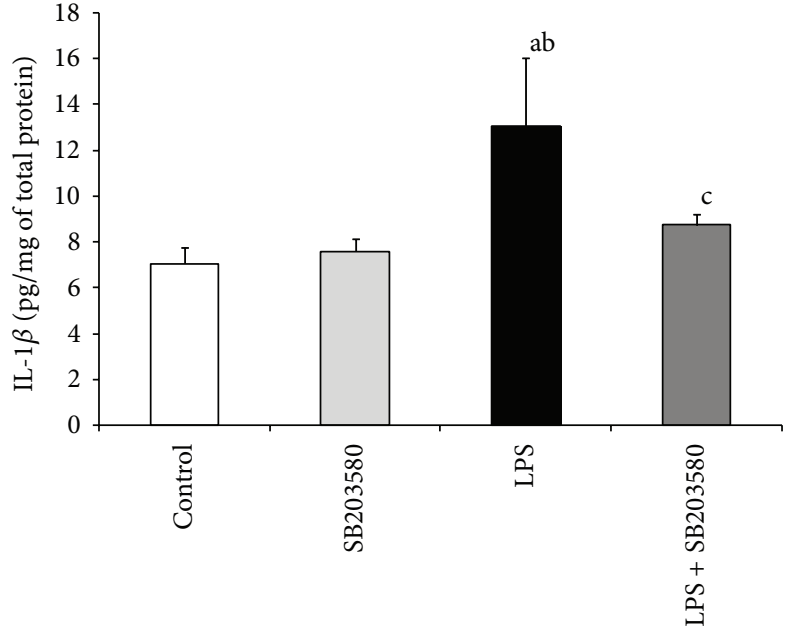

(a)

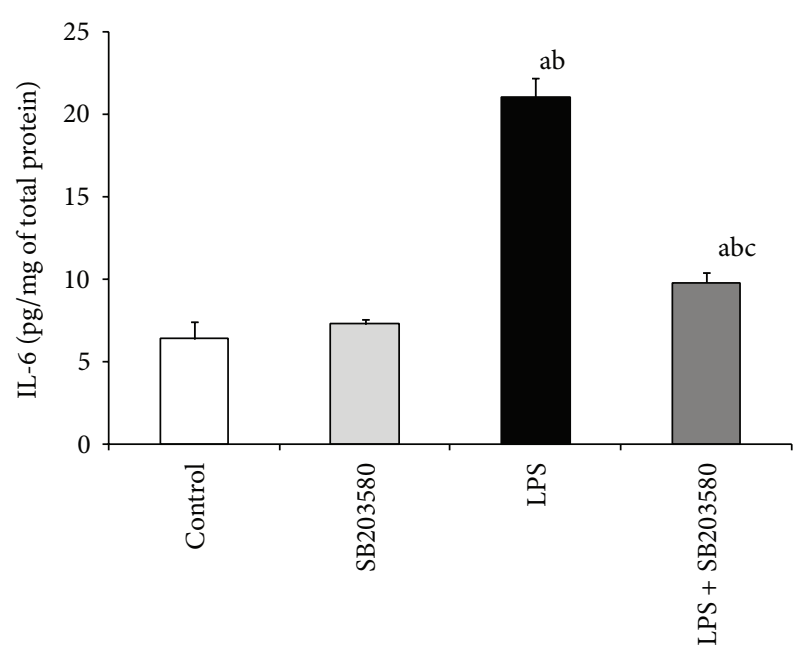

(b)

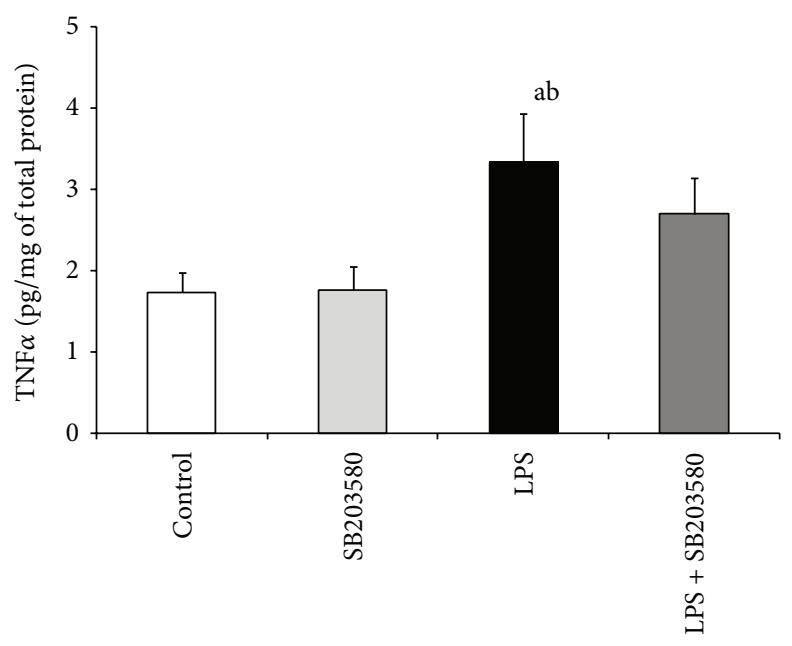

(c)

FIGURE 1: Effect of lipopolysaccharide (LPS) (400 ng/kg; i.v./7 days) and SB203580 (500 $\mu \mathrm{g} / \mathrm{kg}$ ) injections on IL-1 $\beta$ (a), IL-6 (b), and TNF $\alpha$ (c) expression in the hypothalamus on day 7 of the experiment. a, b, $c-P<0.01$ (indicate values that differ significantly from the control, SB203580 control, and LPS treated groups, resp., according to the Mann-Whitney $U$ test). Data are presented as a mean value \pm S.E.M.

did not prevent LPS and IL-1 $\beta$ induced expression of IL-1 $\beta$ but did inhibit the IL-1 $\beta$-induced expression of $\mathrm{c}$-fos and inducible nitric oxide synthase [47]. It is worth noticing that the anti-inflammatory effect of SB203580 has been also described in the in vivo study. In the experiment carried out on mice and rat, treatment with SB203580 for $30 \mathrm{~min}$ prior to the injection of bacterial endotoxin suppressed the plasma level of TNF $\alpha$ at the dose-dependent manner [48]. In the same study, SB203580 also inhibited the circulating concentration of both IL- 6 and TNF $\alpha$ in rat and mice with experimentally induced arthritis. Moreover, treatment with SB203580 reduced mortality in a murine model of endotoxininduced shock. Anti-inflammatory effects of SB203580 and its possible therapeutic use were also determined in the mice with experimentally induced endometriosis. It was shown that repeated for 24-day injection of SB203580 strongly reduced the synthesis of IL-1 $\beta$ and TNF $\alpha$ translation in the mice endometrium [49].
Our study also demonstrated that i.v. injection of SB203580 attenuates endotoxin-dependent synthesis of the proinflammatory cytokines in the hypothalamus. The peripheral administration of the p38 MAPK inhibitor restored synthesis of IL-1 $\beta$ to the control value and reduced IL6 expression in the hypothalamus. However, the effect of SB203580 on the synthesis of hypothalamic TNF $\alpha$ was observed only in the case of transcriptomic analysis. The lack of effect of p38 MAPK inhibition on TNF $\alpha$ synthesis at the level of protein expression could be connected with relatively low elevation of this cytokine in the hypothalamus and limited sensitivity of ELISA assay. However, it should be emphasized that the effectiveness of anti-inflammatory treatment did not require blockade of all proinflammatory cytokines. There is evidence that cytokines exist in "cascades" and that interrupting one cytokine interrupts the cascade [50]; for example, blocking TNF $\alpha$ reduces the activity of IL-6 and IL-1 $\beta$ [51] while blocking IL-1 $\beta$ reduces IL-6 [52]. 


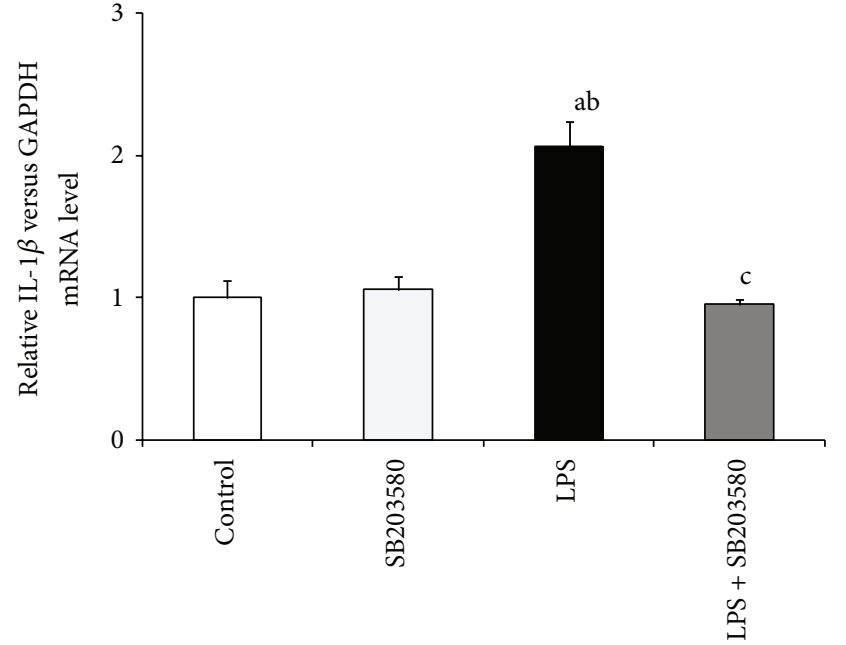

(a)

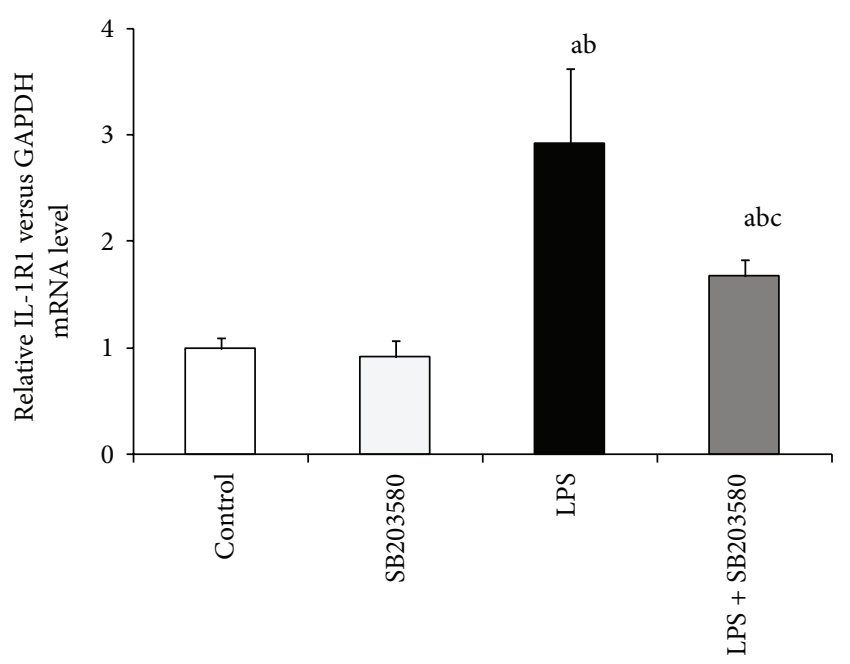

(b)

FIGURE 2: Influence of lipopolysaccharide (LPS) (400 ng/kg; i.v./7 days) and SB203580 (500 $\mu \mathrm{g} / \mathrm{kg})$ injections on the gene expression of IL-1 $\beta$ (a) and IL-1R1 (b) in the hypothalamus on day 7 of the experiment. a, b, c-P 0.01 (indicate values that differ significantly from the control, SB203580 control, and LPS treated groups, resp., according to the Mann-Whitney $U$ test). Data are presented as a mean value \pm S.E.M.

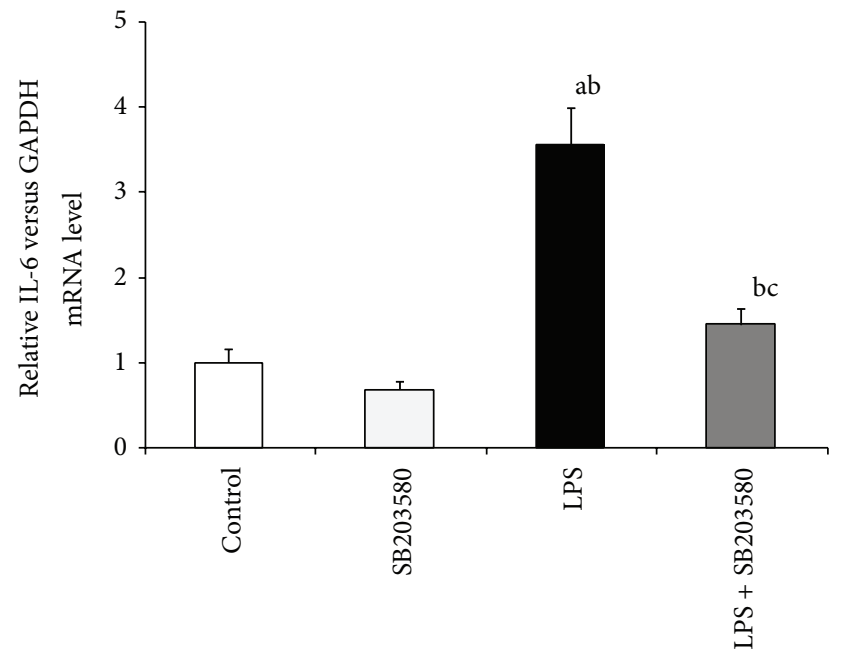

(a)

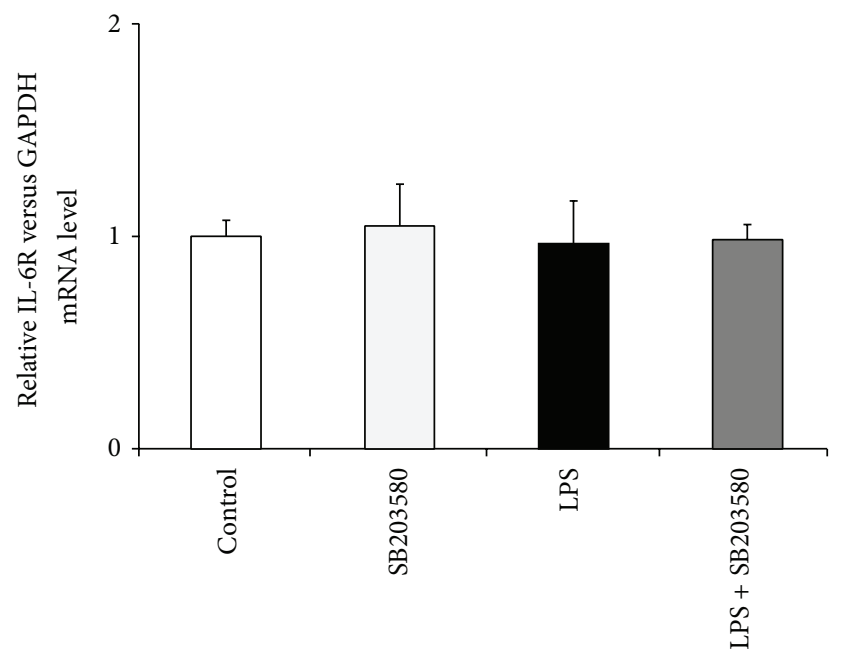

(b)

FIGURE 3: Effect of lipopolysaccharide (LPS) (400 ng/kg; i.v./7 days) and SB203580 (500 $\mu \mathrm{g} / \mathrm{kg}$ ) injections on the gene expression of IL-6 (a) and IL-6R (b) in the hypothalamus on day 7 of the experiment. a, b, $c-P<0.01$ (indicate values that differ significantly from the control, SB203580 control, and LPS treated groups, resp., according to the Mann-Whitney $U$ test). Data are presented as a mean value \pm S.E.M.

Our study determined that changes in the synthesis of cytokines and their receptors after peripheral administration of SB203580 do not have to be an effect of direct inhibition of p38 MAPK in the hypothalamic tissue. It is possible that SB203580 attenuates the peripheral inflammatory response reflecting on reduced inflammatory signal and reduced proinflammatory cytokines synthesis in the hypothalamus. The study conducted on mice demonstrated that reduction of the peripheral inflammatory response using the antiinflammatory drug which did not cross the blood-brain barrier was enough to suppress the brain synthesis of IL- $1 \beta$ [53]. This suggested that even a relatively small reduction of peripheral cytokines, particularly IL- $1 \beta$, may translate into greater attenuation of cytokines synthesis in the brain. This may be because LPS-induced production of IL- $1 \beta$ in the periphery must exceed a fairly high threshold to increase the levels of IL- $1 \beta$ in the brain [53]. One of the endogenous mechanisms controlling the synthesis of proinflammatory cytokines is effect of choline. It was reported that direct stimulation of the vagus nerve or pharmacological inhibition of acetylcholinesterase activated the cholinergic antiinflammatory pathway which suppressed systemic production of cytokines such as TNF $\alpha$, IL-1, and IL-6 [54]. The studies carried out on rats showed that intrathecal injection of SB203580 caused a 3-fold rise in the high-frequency power spectral component of heart rate variability which 


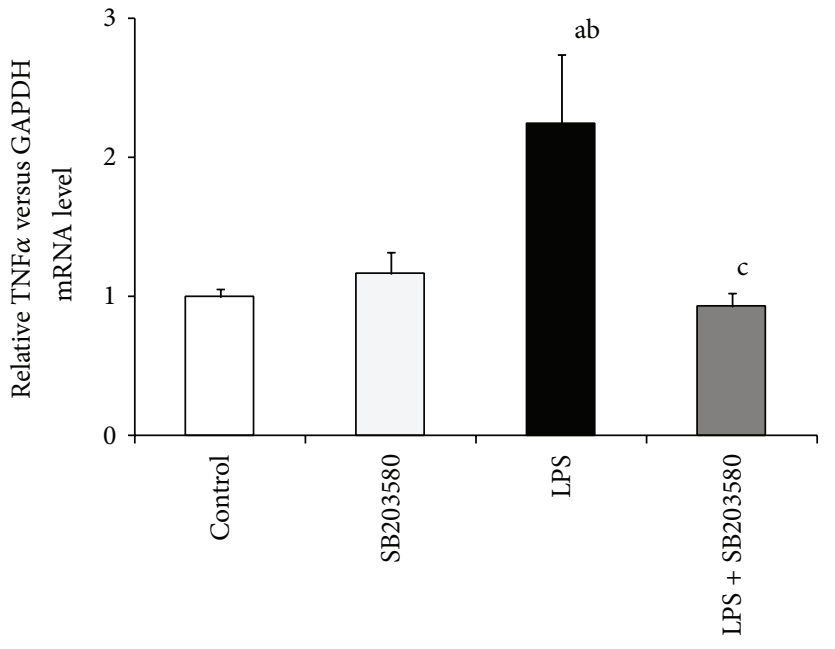

(a)

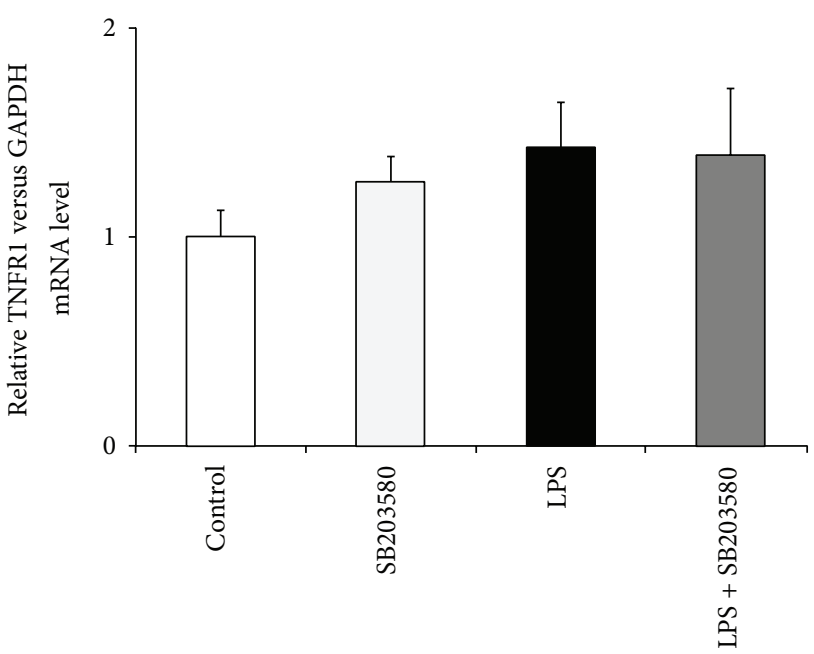

(b)

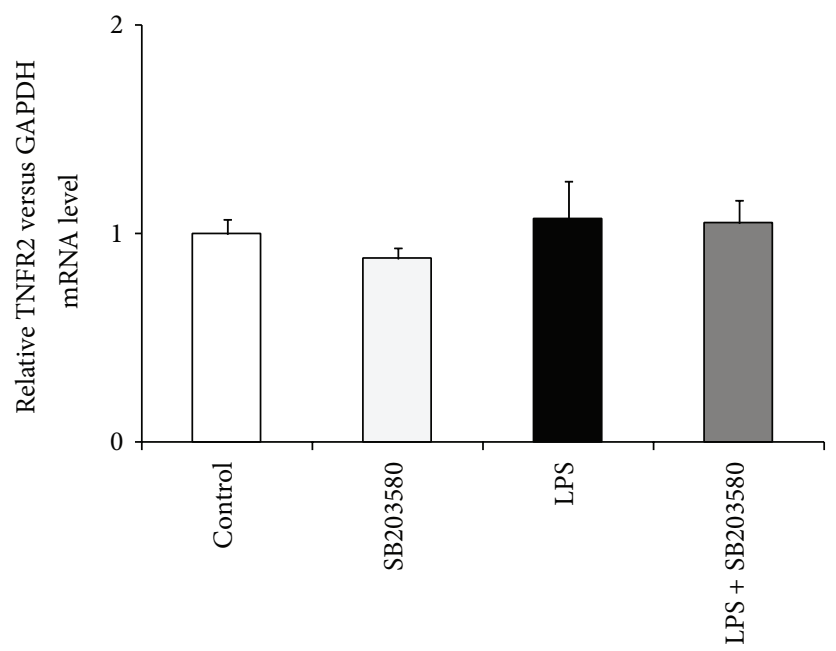

(c)

FiguRE 4: Effect of lipopolysaccharide (LPS) (400 ng/kg; i.v./7 days) and SB203580 (500 $\mu \mathrm{g} / \mathrm{kg})$ injections on the gene expression of TNF $\alpha$ (a), TNFR1 (b), and TNFR2 (c) in the hypothalamus on day 7 of the experiment. a, b, $c-P<0.01$ (indicate values that differ significantly from the control, SB203580 control, and LPS treated groups, resp., according to the Mann-Whitney $U$ test). Data are presented as a mean value \pm S.E.M.

is a widely used parameter of parasympathetic activity that directly correlates with activation of the cholinergic antiinflammatory pathway [55]. Thus, the ability of SB203580 inhibitors to activate the vagus nerve could at least partially explain observed reduction of proinflammatory cytokines synthesis in our study.

The findings that inhibiting p38 MAPK blocks LPSinduced proinflammatory cytokine production seem to initiate new perspectives in the treatment of chronic inflammatory diseases also in the central nervous system. However, recent studies suggest that the role of p38 MAPK during inflammation may be more complex and ambiguous [56]. It was reported that p38 MPAK is also involved in the activation of anti-inflammatory processes. In myeloid cells activation of p38 MAPK signaling pathway limited inflammation in a UVinduced irradiation model [57]. This immunomodulatory effect of p38 MAPK seems to be mediated by the induction of the anti-inflammatory cytokine IL-10 and the inhibition of proinflammatory IL-12 [56-59]. It should be noted that the results of in vitro study on primary human monocytes demonstrated that SB203580 produced profound inhibition of spontaneous production of IL-1 and TNF $\alpha$. Unfortunately, it was also determined that SB203580 significantly increases LPS-stimulated IL- 6 production and decreases the synthesis of anti-inflammatory IL-10 in primary human monocytes [60]. These potential proinflammatory effects of SB203580 treatment suggest that all therapy using p38 MAPK inhibitors should be performed cautiously and with analysis conducted on expected and unexpected consequences of the treatment.

\section{Conflict of Interests}

All of the authors have declared there is no conflict of interests regarding the publication of this work. 


\section{Acknowledgment}

This research was supported by Grant MNiSW "Iuventus Plus" no. IP2011 017371.

\section{References}

[1] M. J. Kluger, "Fever: role of pyrogens and cryogens," Physiological Reviews, vol. 71, no. 1, pp. 93-127, 1991.

[2] C. B. Lawrence and N. J. Rothwell, "Anorexic but not pyrogenic actions of interleukin-1 are modulated by central melanocortin$3 / 4$ receptors in the rat," Journal of Neuroendocrinology, vol. 13, no. 6, pp. 490-495, 2001.

[3] A. P. Herman and D. Tomaszewska-Zaremba, "Effect of endotoxin on the expression of GnRH and GnRHR genes in the hypothalamus and anterior pituitary gland of anestrous ewes," Animal Reproduction Science, vol. 120, no. 1-4, pp. 105-111, 2010.

[4] O. Ebisui, J. Fukata, T. Tominaga et al., "Roles of interleukin$1 \alpha$ and $-1 \beta$ in endotoxin-induced suppression of plasma gonadotropin levels in rats," Endocrinology, vol. 130, no. 6, pp. 3307-3313, 1992.

[5] M. Palomba and M. Bentivoglio, "Chronic inflammation affects the photic response of the suprachiasmatic nucleus," Journal of Neuroimmunology, vol. 193, no. 1-2, pp. 24-27, 2008.

[6] M. A. Erickson and W. A. Banks, "Cytokine and chemokine responses in serum and brain after single and repeated injections of lipopolysaccharide: multiplex quantification with path analysis," Brain, Behavior, and Immunity, vol. 25, no. 8, pp. 16371648, 2011.

[7] A. A. Creasey, P. Stevens, J. Kenney et al., "Endotoxin and cytokine profile in plasma of baboons challenged with lethal and sublethal Escherichia coli," Circulatory Shock, vol. 33, no. 2, pp. 84-91, 1991.

[8] A. P. Herman, T. Misztal, A. Herman, and D. TomaszewskaZaremba, "Expression of Interleukin (IL)-1 $\beta$ and IL-1 receptors genes in the hypothalamus of anoestrous ewes after lipopolysaccharide treatment," Reproduction in Domestic Animals, vol. 45, no. 6, pp. e426-e433, 2010.

[9] M. G. de Simoni, L. Terreni, R. Chiesa, F. Mangiarotti, and G. L. Forloni, "Inteferon- $\gamma$ potentiates interleukin (IL)- 6 and tumor necrosis factor- $\alpha$ but not IL- $1 \beta$ induced by endotoxin in the brain," Endocrinology, vol. 138, no. 12, pp. 5220-5226, 1997.

[10] W. A. Banks, "Cytokines and the blood-brain barrier," in The Neuroimmunological Basis of Behavior and Mental Disorders, pp. 3-17, Springer, 2009.

[11] R. Dantzer, "Cytokine, sickness behavior, and depression," Neurologic Clinics, vol. 24, no. 3, pp. 441-460, 2006.

[12] W. A. Banks, A. J. Kastin, and R. D. Broadwell, "Passage of cytokines across the blood-brain barrier," NeuroImmunoModulation, vol. 2, no. 4, pp. 241-248, 1995.

[13] Y. Kakizaki, H. Watanobe, A. Kohsaka, and T. Suda, “Temporal profiles of interleukin- $1 \beta$, interleukin- 6 , and tumor necrosis factor- $\alpha$ in the plasma and hypothalamic paraventricular nucleus after intravenous or intraperitoneal administration of lipopolysaccharide in the rat: estimation by push-pull perfusion," Endocrine Journal, vol. 46, no. 4, pp. 487-496, 1999.

[14] M. K. Hansen, K. T. Nguyen, L. E. Goehler et al., "Effects of vagotomy on lipopolysaccharide-induced brain interleukin- $1 \beta$ protein in rats," Autonomic Neuroscience: Basic and Clinical, vol. 85, no. 1-3, pp. 119-126, 2000.
[15] S. Laye, R.-M. Bluthe, S. Kent et al., "Subdiaphragmatic vagotomy blocks induction of IL- $1 \beta$ mRNA in mice brain in response to peripheral LPS," American Journal of Physiology. Regulatory Integrative and Comparative Physiology, vol. 268, no. 5, pp. R1327-R1331, 1995.

[16] G. P. Chrousos, "The stress response and immune function: clinical implications. The 1999 Novera H. Spector lecture," Annals of the New York Academy of Sciences, vol. 917, pp. 38-67, 2000.

[17] P. Taishi, L. Churchill, A. De, F. Obal Jr., and J. M. Krueger, "Cytokine mRNA induction by interleukin- $1 \beta$ or tumor necrosis factor $\alpha$ in vitro and in vivo," Brain Research, vol. 1226, pp. 89-98, 2008.

[18] R. E. Mrak and W. S. T. Griffin, "Interleukin-1 and the immunogenetics of Alzheimer disease," Journal of Neuropathology and Experimental Neurology, vol. 59, no. 6, pp. 471-476, 2000.

[19] L. Vitkovic, J. Bockaert, and C. Jacque, “Inflammatory' cytokines' neuromodulators in normal brain?" Journal of Neurochemistry, vol. 74, no. 2, pp. 457-471, 2000.

[20] S. V. Vellucci, R. F. Parrott, A. C. Da Costa, S. Ohkura, and K. M. Kendrick, "Increased body temperature, cortisol secretion, and hypothalamic expression of c-fos, corticotrophin releasing hormone and interleukin- $1 \beta$ mRNAs, following central administration of interleukin- $1 \beta$ in the sheep," Molecular Brain Research, vol. 29, no. 1, pp. 64-70, 1995.

[21] A. P. Herman, T. Misztal, K. Romanowicz, and D. TomaszewskaZaremba, "Central injection of exogenous IL-1 $\beta$ in the control activities of hypothalamic-pituitary-gonadal axis in anestrous ewes," Reproduction in Domestic Animals, vol. 47, no. 1, pp. 4452, 2012.

[22] S. Rivest and C. Rivier, "Centrally injected interleukin-1 beta inhibits the hypothalamic LHRH secretion and circulating LH levels via prostaglandins in rats," Journal of Neuroendocrinology, vol. 5, no. 4, pp. 445-450, 1993.

[23] S. Kumar, M. S. Jiang, J. L. Adams, and J. C. Lee, "Pyridinylimidazole compound SB 203580 inhibits the activity but not the activation of p38 mitogen-activated protein kinase," Biochemical and Biophysical Research Communications, vol. 263, no. 3, pp. 825-831, 1999.

[24] S. P. Davies, H. Reddy, M. Caivano, and P. Cohen, "Specificity and mechanism of action of some commonly used protein kinase inhibitors," Biochemical Journal, vol. 351, no. 1, pp. 95105, 2000.

[25] J. J. Baldassare, Y. Bi, and C. J. Bellone, “The role of p38 mitogenactivated protein kinase in IL- $1 \beta$ transcription," Journal of Immunology, vol. 162, no. 9, pp. 5367-5373, 1999.

[26] J. C. Lee, J. T. Laydon, P. C. McDonnell et al., "A protein kinase involved in the regulation of inflammatory cytokine biosynthesis," Nature, vol. 372, no. 6508, pp. 739-746, 1994.

[27] C. Thirunavukkarasu, S. C. Watkins, and C. R. Gandhi, "Mechanisms of endotoxin-induced NO, IL- 6 , and TNF- $\alpha$ production in activated rat hepatic stellate cells: role of p38 MAPK," Hepatology, vol. 44, no. 2, pp. 389-398, 2006.

[28] J. Welento, S. Szteyn, and Z. Milart, "Observations on the stereotaxic configuration of the hypothalamus nuclei in the sheep," Anatomischer Anzeiger, vol. 124, no. 1, pp. 1-27, 1969.

[29] R. Rasmussen, "Quantification on the LightCycler," in Rapid Cycle Real-Time PCR Methods and Applications, S. Meuer, C. Wittwer, and K. Nakagawara, Eds., Berlin, Germany, 2001. 
[30] M. W. Pfaffl, A. Tichopad, C. Prgomet, and T. P. Neuvians, "Determination of stable housekeeping genes, differentially regulated target genes and sample integrity: bestKeeper-excelbased tool using pair-wise correlations," Biotechnology Letters, vol. 26, no. 6, pp. 509-515, 2004.

[31] S. Layé, G. Gheusi, S. Cremona et al., "Endogenous brain IL1 mediates LPS-induced anorexia and hypothalamic cytokine expression," American Journal of Physiology. Regulatory Integrative and Comparative Physiology, vol. 279, no. 1, pp. R93-R98, 2000.

[32] A. J. Dunn, "Effects of cytokines and infections on brain neurochemistry," Clinical Neuroscience Research, vol. 6, no. 1-2, pp. 52-68, 2006.

[33] N. J. Busbridge, M. J. Dascombe, F. J. H. Tilders, J. W. A. M. Van Oers, E. A. Linton, and N. J. Rothwell, "Central activation of thermogenesis and fever by interleukin- $1 \beta$ and interleukin$1 \alpha$ involves different mechanisms," Biochemical and Biophysical Research Communications, vol. 162, no. 2, pp. 591-596, 1989.

[34] A. J. Dunn, "Cytokine activation of the HPA axis," Annals of the New York Academy of Sciences, vol. 917, pp. 608-617, 2000.

[35] T. M. O'Connor, D. J. O'Halloran, and F. Shanahan, “The stress response and the hypothalamic-pituitary-adrenal axis: from molecule to melancholia," QJM, vol. 93, no. 6, pp. 323-333, 2000.

[36] L. Yang, K. Lindholm, Y. Konishi, R. Li, and Y. Shen, “Target depletion of distinct tumor necrosis factor receptor subtypes reveals hippocampal neuron death and survival through different signal transduction pathways," Journal of Neuroscience, vol. 22, no. 8, pp. 3025-3032, 2002.

[37] R. A. French, R. W. Vanhoy, R. Chizzonite et al., "Expression and localization of p80 and p68 interleukin-1 receptor proteins in the brain of adult mice," Journal of Neuroimmunology, vol. 93, no. 1-2, pp. 194-202, 1999.

[38] P. März, K. Heese, B. Dimitriades-Schmutz, S. Rose-John, and U. Otten, "Role of interleukin-6 and soluble IL-6 receptor in region-specific induction of astrocytic differentiation and neurotrophin expression," Glia, vol. 26, no. 3, pp. 191-200, 1999.

[39] E. M.-H. Ban, "Interleukin-1 receptors in the brain: characterization by quantitative in situ autoradiography," ImmunoMethods, vol. 5, no. 1, pp. 31-40, 1994.

[40] A. P. Herman, A. Krawczyńska, J. Bochenek et al., "Inhibition of acetylcholinesterase activity by rivastigmine decreases lipopolysaccharide-induced IL- $1 \beta$ expression in the hypothalamus of ewes," Domestic Animal Endocrinology, vol. 44, no. 3, pp. 109-114, 2013.

[41] M.-M. Gabellec, R. Griffais, G. Fillion, and F. Haour, "Interleukin-1 receptors type I and type II in the mouse brain: kinetics of mRNA expressions after peripheral administration of bacterial lipopolysaccharide," Journal of Neuroimmunology, vol. 66, no. 1-2, pp. 65-70, 1996.

[42] T. Takao, K. Hashimoto, and E. B. de Souza, "Interleukin1 receptors in the brain-endocrine-immune axis-modulation by stress and infection," Annals of the New York Academy of Sciences, vol. 771, pp. 372-385, 1995.

[43] C. Patil, X. Zhu, C. Rossa Jr., Y. J. Kim, and K. L. Kirkwood, “p38 MAPK regulates IL- $1 \beta$ induced IL-6 expression through mRNA stability in osteoblasts," Immunological Investigations, vol. 33, no. 2, pp. 213-233, 2004.

[44] A. Cuenda and S. Rousseau, "p38 MAP-Kinases pathway regulation, function and role in human diseases," Biochimica et Biophysica Acta. Molecular Cell Research, vol. 1773, no. 8, pp. 1358-1375, 2007.
[45] L. Shapiro and C. A. Dinarello, "Osmotic regulation of cytokine synthesis in vitro," Proceedings of the National Academy of Sciences of the United States of America, vol. 92, no. 26, pp. 12230-12234, 1995.

[46] R. Beyaert, A. Cuenda, W. V. Berghe et al., “The p38/RK mitogen-activated protein kinase pathway regulates interleukin-6 synthesis in response to tumour necrosis factor," EMBO Journal, vol. 15, no. 8, pp. 1914-1923, 1996.

[47] A. Simi, M. Porsmyr-Palmertz, A. Hjertén, M. IngelmanSundberg, and N. Tindberg, "The neuroprotective agents chlomethiazole and SB203580 inhibit IL- $1 \beta$ signalling but not its biosynthesis in rat cortical glial cells," Journal of Neurochemistry, vol. 83, no. 3, pp. 727-737, 2002.

[48] A. M. Badger, J. N. Bradbeer, B. Votta, J. C. Lee, J. L. Adams, and D. E. Griswold, "Pharmacological profile of SB 203580, a selective inhibitor of cytokine suppressive binding protein/p38 kinase, in animal models of arthritis, bone resorption, endotoxin shock and immune function," Journal of Pharmacology and Experimental Therapeutics, vol. 279, no. 3, pp. 1453-1461, 1996.

[49] W.-D. Zhou, H.-M. Yang, Q. Wang et al., "SB203580, a p38 mitogen-activated protein kinase inhibitor, suppresses the development of endometriosis by down-regulating proinflammatory cytokines and proteolytic factors in a mouse model," Human Reproduction, vol. 25, no. 12, pp. 3110-3116, 2010.

[50] C. A. Dinarello, "Anti-inflammatory agents: present and future," Cell, vol. 140, no. 6, pp. 935-950, 2010.

[51] Y. Fong, K. J. Tracey, L. L. Moldawer et al., "Antibodies to cachectin/tumor necrosis factor reduce interleukin $1 \beta$ and interleukin 6 appearance during lethal bacteremia," Journal of Experimental Medicine, vol. 170, no. 5, pp. 1627-1633, 1989.

[52] R. Goldbach-Mansky, N. J. Dailey, S. W. Canna et al., "Neonatal-onset multisystem inflammatory disease responsive to interleukin-1 $\beta$ inhibition," New England Journal of Medicine, vol. 355, no. 6, pp. 581-592, 2006.

[53] Y. Pollak, A. Gilboa, O. Ben-Menachem, T. Ben-Hur, H. Soreq, and R. Yirmiya, "Acetylcholinesterase inhibitors reduce brain and blood interleukin-1 $\beta$ production," Annals of Neurology, vol. 57, no. 5, pp. 741-745, 2005.

[54] L. V. Borovikova, S. Ivanova, M. Zhang et al., "Vagus nerve stimulation attenuates the systemic inflammatory response to endotoxin," Nature, vol. 405, no. 6785, pp. 458-462, 2000.

[55] J.-M. Waldburger, D. L. Boyle, M. Edgar et al., "Spinal p38 MAP kinase regulates peripheral cholinergic outflow," Arthritis and Rheumatism, vol. 58, no. 9, pp. 2919-2921, 2008.

[56] K. Katholnig, C. C. Kaltenecker, H. Hayakawa et al., "P38 $\alpha$ senses environmental stress to control innate immune responses via mechanistic target of rapamycin," Journal of Immunology, vol. 190, no. 4, pp. 1519-1527, 2013.

[57] C. Kim, Y. Sano, K. Todorova et al., "The kinase p38 $\alpha$ serves cell type-specific inflammatory functions in skin injury and coordinates pro- and anti-inflammatory gene expression," Nature Immunology, vol. 9, no. 9, pp. 1019-1027, 2008.

[58] Z. Yang, X. Zhang, P. A. Darrah, and D. M. Mosser, "The regulation of Th1 responses by the p38 MAPK," Journal of Immunology, vol. 185, no. 10, pp. 6205-6213, 2010.

[59] X. Guo, R. E. Gerl, and J. W. Schrader, "Defining the involvement of p38 $\alpha$ MAPK in the production of anti- and proinflammatory cytokines using an SB 203580-resistant form of the kinase," Journal of Biological Chemistry, vol. 278, no. 25, pp. 22237-22242, 2003. 
[60] T. H. Page, A. Brown, E. M. Timms, B. M. J. Foxwell, and K. P. Ray, "Inhibitors of p38 suppress cytokine production in rheumatoid arthritis synovial membranes: does variable inhibition of interleukin-6 production limit effectiveness in vivo," Arthritis and Rheumatism, vol. 62, no. 11, pp. 3221-3231, 2010. 


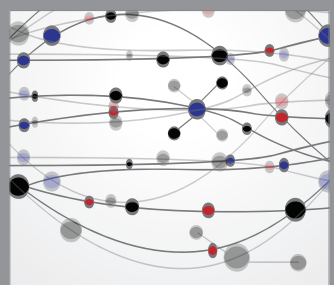

The Scientific World Journal
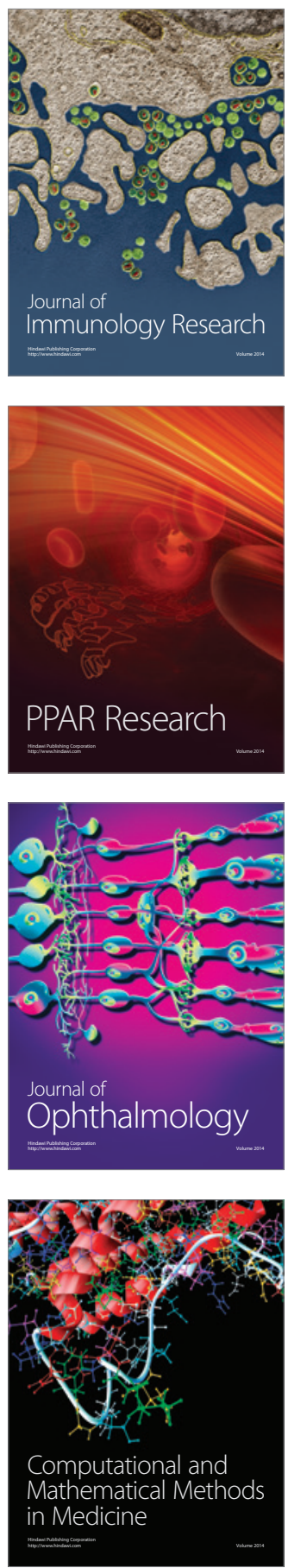

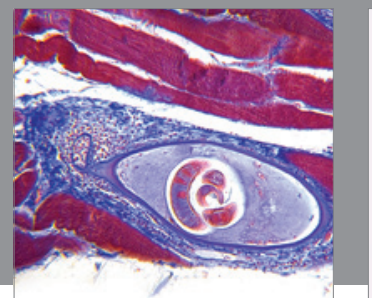

Gastroenterology

Research and Practice
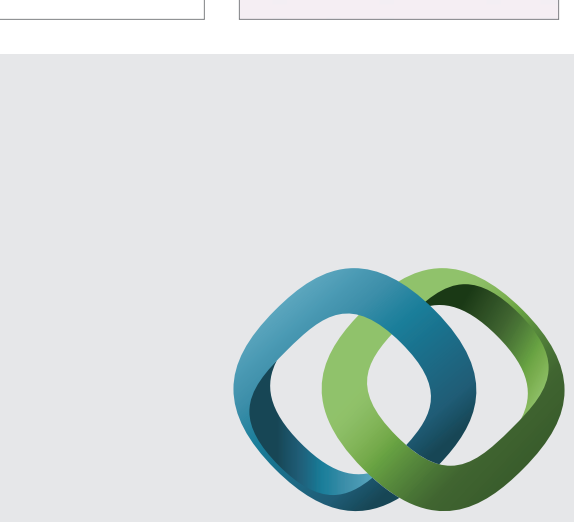

\section{Hindawi}

Submit your manuscripts at

http://www.hindawi.com
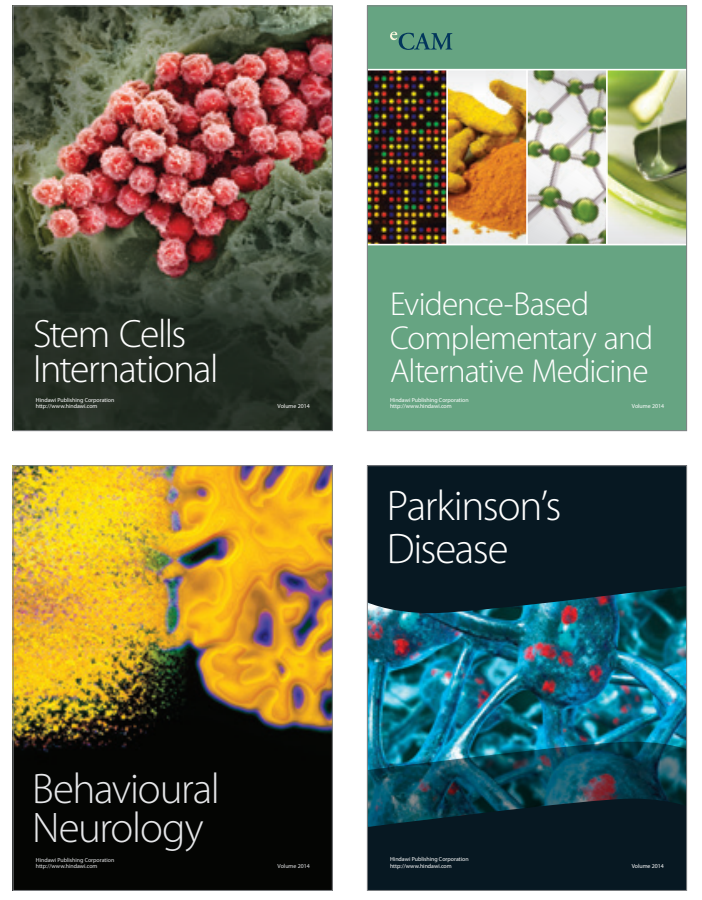
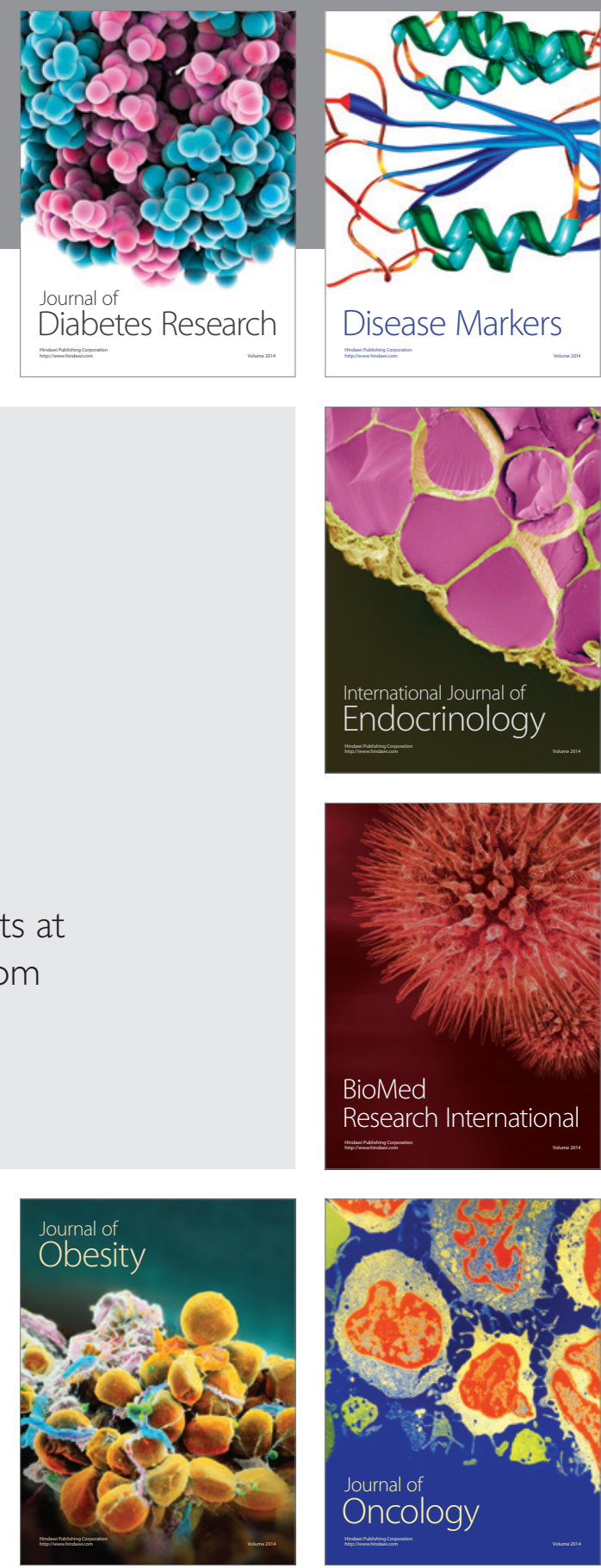

Disease Markers
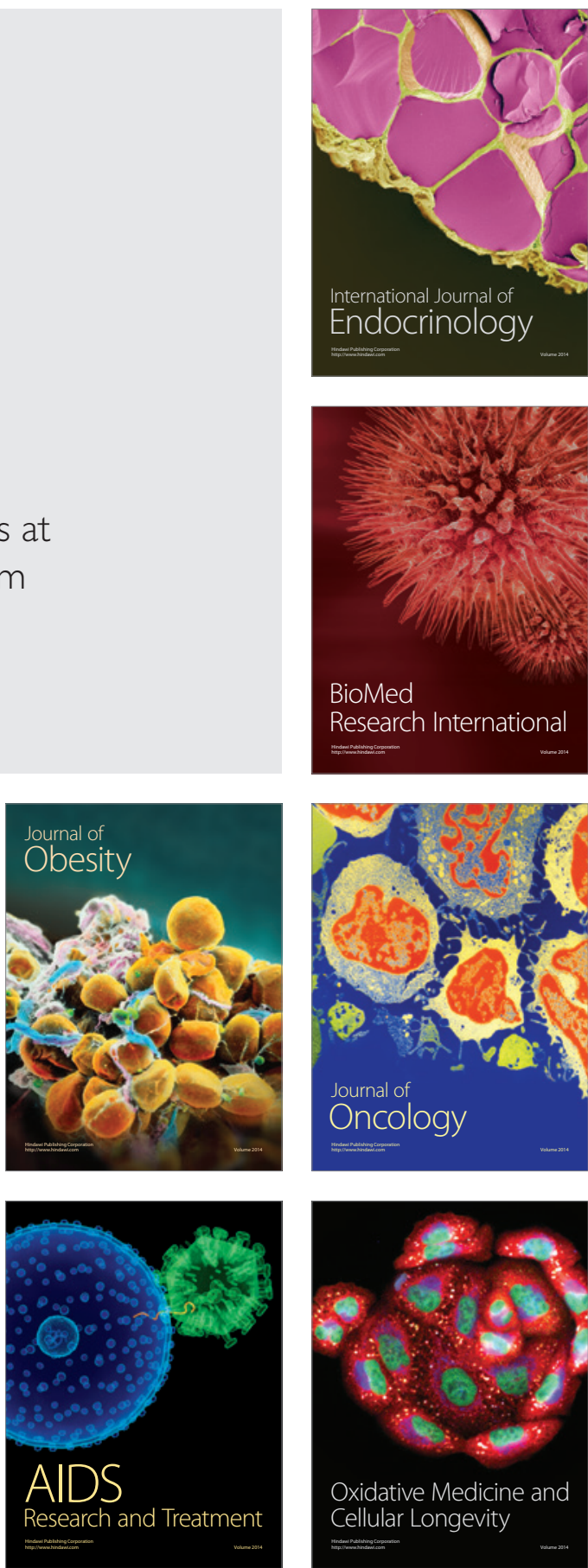